\title{
SEMA3F wt Allele
}

National Cancer Institute

\section{Source}

National Cancer Institute. SEMA3F wt Allele. NCI Thesaurus. Code C106008.

Human SEMA3F wild-type allele is located in the vicinity of $3 p 21.3$ and is approximately 34 $\mathrm{kb}$ in length. This allele, which encodes semaphorin-3F protein, plays a role in both axon guidance and cell signaling. 